\title{
PRINSIP KERJA SAMA DALAM INTERAKSI JUAL BELI DI PASAR TRADISIONAL BANYUASRI DAN IMPLIKASINYA TERHADAP PEMBELAJARAN TEKS NEGOSIASI
}

\author{
Ni Made Sauca Yukti ${ }^{1}$, I Wayan Artika², I Wayan Rasna ${ }^{3}$ \\ Jurusan Pendidikan Bahasa dan Sastra Indonesia \\ Universitas Pendidikan Ganesha \\ Singaraja, Indonesia \\ e-mail: sauca_yukti@yahoo.co.id¹, wayan.artika@undiksha.ac.id², \\ wayanrasna@ymail.com ${ }^{3}$
}

\begin{abstract}
ABSTRAK
Penelitian ini bertujuan untuk mengkaji bentuk pematuhan dan bentuk pelanggaran prinsip kerja sama dalam interaksi jual beli di Pasar Tradisional Banyuasri serta implikasinya terhadap pembelajaran teks negosiasi di kelas X. Penelitian ini menggunakan pendekatan deskriptif kualitatif. Subjek dalam penelitian ini adalah penjual dan pembeli, sedangkan objeknya adalah prinsip kerja sama. Data dikumpulkan menggunakan metode observasi nonpartisipatif dan metode dokumentasi. Data dalam penelitian ini dianalisis secara deskriptif kualitatif. Hasil penelitian ini menunjukkan (1) bentuk pematuhan prinsip kerja sama pada tuturan penjual berjumlah 480 tuturan meliputi, maksim kuantitas $124(25,83 \%)$, maksim kualitas 63 (13,12\%), maksim relevansi $290(60,42 \%)$, dan maksim pelaksanaan $3(0,63 \%)$. Sementara pematuhan prinsip kerja sama pada tuturan pembeli berjumlah 472 tuturan meliputi, maksim kuantitas 9 (1,91\%), maksim kualitas $326(69,07 \%)$, maksim relevansi 56 (11,86\%), dan maksim pelaksanaan $81(17,16 \%)$; (2) bentuk pelanggaran prinsip kerja sama pada tuturan penjual berjumlah 34 tuturan meliputi, maksim kuantitas $5(14,71 \%)$, maksim kualitas 18 (52,94\%), maksim relevansi 6 $(17,65 \%)$, dan maksim pelaksanaan $5(14,71 \%)$. Sementara pelanggaran pada tuturan pembeli berjumlah 106 tuturan meliputi, maksim kualitas 83 (78,30\%), maksim relevansi 2 (1,89\%), dan maksim pelaksanaan $21(19,81 \%)$ tuturan; serta (3) penelitian ini berimplikasi terhadap pembelajaran teks negosiasi kelas $\mathrm{X}$ dilihat dari kesesuaiannya terhadap kompetensi dasar.
\end{abstract}

Kata-kata kunci: negosiasi, kerja sama, prinsip kerja sama, teks

\begin{abstract}
This research aimed to review the obedience and violation of cooperative principle form at Banyuasri Traditional market and its implication to the negotiation text learning in ninth grade. This research uses descriptive qualitative approach. The subject of this research are the traders and the buyers and the object of this research is cooperative principle. Data are collected uses non participated observation method and documentation method by using written technique. The data in this research is analyzed in accordance with qualitative descriptive. The result of this research shows that (1) The form of the obedience of cooperative principle at traders discourse are 480 discourse comprise of maxim of quantity $124(25,83 \%)$, maxim of quality $63(13,12 \%)$, maxim of relevance $290(60,42 \%)$, and maxim of manner $3(0,63 \%)$. Whereas the form of the obedience of cooperative principle at buyer discourse are 472 discourse comprise of maxim of quantity $9(1,91 \%)$, maxim of quality $326(69,07 \%)$, maxim of relevance $56(11,86 \%)$, and maxim of manner $81(17,16 \%)$; $(2)$ The form of the violation of cooperative principle in trader discourse are 34 discourses comprise of maxim of quantity $5(14,71 \%)$, maxim of quality $18(52,94 \%)$, maxim of relevance $6(17,65 \%)$, and maxim of manner $5(14,71 \%)$. Whereas the form of the violation of cooperative principle in buyer discourse are 106 discourses comprise of maxim of
\end{abstract}


quality $83(78,30 \%)$, maxim of relevance 2 (1,89\%), and maxim of manner $21(19,81 \%)$; (3) This research has implication to the negotiation text learning of ninth grade since it can support the learning material on basic competency.

Key words: negotiation, cooperative, cooperative principle, text

\section{PENDAHULUAN}

Pasar adalah tempat berkumpulnya orang-orang untuk memperoleh berbagai kebutuhan yang diinginkan. Bilas (1992:5) menyebutkan, "pada waktu silam, pasar diartikan menurut lokasi geografis, tetapi saat ini pasar tidak mempunyai batas-batas geografis karena komunikasi modern memungkinkan pembeli dan penjual bertemu tanpa melihat wajah yang satu dengan yang lain". Baik pasar pada waktu silam maupun pasar saat ini, keduanya tetap memiliki ciri khas yang sama, yaitu adanya transaksi jual beli barang atau jasa.

Transaksi jual beli di pasar tidak hanya dapat dikaji dari segi ekonomi, tetapi hal ini juga penting dikaji dari segi bahasa. Dalam transaksi terjadi interaksi timbal balik antara penjual dan pembeli. Interaksi tersebut tidak dapat berjalan dengan baik tanpa adanya bahasa sebagai sarana penyampaian informasi. Hal ini sejalan dengan pendapat Djatmika (2014:1) yang menyatakan bahwa "secara sosial dan kultural seorang manusia harus berinteraksi dengan manusia lain guna memenuhi kebutuhan masing-masing".

Fuad, dkk. (2000:11) menyatakan, "berdasarkan cara transaksinya, pasar dikelompokkan menjadi pasar tradisional dan pasar modern". Pasar tradisional ditandai oleh adanya transaksi langsung antara penjual dan pembeli serta terdapat proses tawar-menawar (negosiasi). Bahkan tidak jarang pula terjalin percakapan yang akrab di antara kedua pihak tersebut. Sebaliknya, di pasar modern penjual dan pembeli tidak bertransaksi secara langsung melainkan langsung melihat label harga yang sudah tertera pada barang. Hal tersebut menunjukkan bahwa interaksi yang terjadi di pasar tradisional lebih banyak dibandingkan pasar modern sehingga pasar tradisional sangat menarik dikaji dari segi bahasa.
Interaksi yang terjadi di pasar menggunakan ragam bahasa yang khas. Bahasa di pasar cenderung singkat dan tanpa ada basa-basi, baik dari penjual maupun pembeli. Selain singkat, bahasa yang digunakan di areal pasar juga tidak memperhatikan kaidah bahasa Indonesia baku. Hal ini sejalan dengan pendapat Syahroni, dkk. (2013:16) yang menyatakan bahwa "dalam situasi tak resmi seperti di rumah, di pasar, seorang penutur tidak dituntut menggunakan bahasa baku".

Beragam penjual dan pembeli yang ada di pasar tradisional, baik itu dari segi pekerjaan, pendidikan, usia, etnis, dan sebagainya juga sangat berpengaruh terhadap bahasa yang digunakan. Bahasa yang digunakan di pasar tradisional pada umumnya adalah bahasa daerah setempat karena sebagian besar penjual berasal dari seputaran lokasi pasar tersebut. Namun, tidak jarang pula digunakan bahasa Indonesia apabila pembeli memulai interaksi menggunakan bahasa Indonesia.

Keberagaman bahasa tersebut menuntut adanya kerja sama agar interaksi dapat berjalan dengan baik. Selain penggunaan bahasa yang khas, kondisi di pasar tradisional yang cukup padat juga membutuhkan kerja sama yang baik saat berkomunikasi. Putrayasa (2014:101) mengungkapkan bahwa, "adanya kerja sama yang baik antara penutur dan mitra tutur dalam sebuah percakapan akan memudahkan pertukaran informasi dan penyampaian maksud yang ingin dicapai". Terutama saat negosiasi berlangsung, seperti yang diungkapkan oleh (Kemdikbud, 2015:149) bahwa "negosiasi adalah bentuk interaksi sosial yang berfungsi untuk mencari penyelesaian bersama di antara pihak-pihak yang mempunyai perbedaan kepentingan". Adanya perbedaan kepentingan tersebut membutuhkan kerja sama yang baik saat bernegosiasi. 
Terkait hal tersebut, dalam kajian pragmatik H. Paul Grice mengungkapkan prinsip kerja sama dalam berkomunikasi. Menurut Putrayasa (2014:101), "prinsip kerja sama atau prinsip kooperatif yang dicetuskan oleh Grice (1975) sebagai dasar kesuksesan dalam berkomunikasi”. Kaidah percakapan ini terdiri atas empat maksim, yaitu maksim kuantitas (maxim of quantity), maksim kualitas (maxim of quality), maksim relevansi (maxim of relevance), dan maksim pelaksanaan (maxim of manner) (Rahardi, 2005:53).

Dalam maksim kuantitas (maxim of quantity), penutur diharapkan dapat memberikan informasi yang cukup, realtif memadai, dan seinformatif mungkin. Dalam maksim kualitas (maxim of quantity), penutur diharapkan dapat menyampaikan sesuatu yang nyata dan sesuai fakta di dalam bertutur. Dalam maksim relevansi (maxim of relevance), penutur masingmasing hendaknya dapat memberikan kontribusi yang relevan tentang sesuatu yang sedang dipertuturkan. Terakhir, dalam maksim pelaksanaan (maxim of manner), penutur harus bertutur secara langsung, jelas, dan tidak kabur.

Namun, dalam penerapannya tuturantuturan yang tidak sesuai dengan prinsip kerja sama sangat mungkin terjadi saat bernegosiasi. Salah satu pasar tradisional yang memiliki potensi yang cukup besar terjadi negosiasi adalah Pasar Tradisional Banyuasri. Pasar Tradisional Banyuasri berlokasi di Jalan Jenderal Ahmad Yani No. 174, Banyuasri, Kecamatan Buleleng, Kabupaten Buleleng, Provinsi Bali. Pasar tersebut merupakan pasar yang cukup padat dipenuhi oleh berbagai pedagang, mulai dari pedagang sembako hingga pedagang pakaian. Selain lengkap, alasan lain yang menyebabkan sebagian besar masyarakat Kota Singaraja berbelanja di pasar tersebut karena lokasinya strategis, yaitu di tengah-tengah kota. Kondisi itu menunjukkan besarnya potensi negosiasi yang terjadi sehingga banyak tuturan yang dapat diamati.

Berdasarkan pengamatan awal di Pasar Tradisional Banyuasri, ditemukan tuturan yang melanggar prinsip kerja sama baik yang dilakukan oleh penjual maupun pembeli saat proses negosiasi. Terdapat tuturan yang berlebihan, tidak relevan, dan tidak informatif yang terjadi saat negosiasi. Salah satu tuturan yang ditemukan ketika melakukan pengamatan awal pada Jumat, 17 November 2017, yaitu:

Pembeli : "Kesuna baang lima belas, Bu." (Bawang putih kasi lima belas Bu)

Penjual : "Bawang maan monto."

(Bawang merah dapat segitu)

Tuturan penjual pada percakapan di atas menunjukkan kurangnya relevansi dengan topik yang dibicarakan karena tidak memberikan jawaban terhadap pertanyaan yang disampaikan. Namun, dalam beberapa kesempatan juga ditemukan tuturan yang mematuhi prinsip kerja sama. Hal inilah yang menarik untuk dikaji lebih lanjut mengenai seberapa jauh penerapan prinsip kerja sama dalam interaksi jual beli di pasar tradisional.

Interaksi jual beli juga terdapat dalam Kurikulum 2013 khususnya jenjang SMA, yaitu pada materi teks negosiasi. Pada materi tersebut siswa belajar berdiskusi di antara pihak-pihak yang memiliki kepentingan berbeda dalam bentuk dialog. Oleh karena itu, penting bagi guru untuk mengajarkan kepada siswa cara berkomunikasi yang baik. Beranjak dari hal tersebut, pada penelitian ini juga akan dikaji lebih jauh mengenai implikasi penerapan prinsip kerja sama terhadap pembelajaran teks negosiasi.

Beberapa penelitian sejenis juga telah dilakukan, tetapi memiliki perbedaan dengan penelitian yang peneliti rancang. Penelitian yang mengkaji prinsip kerja sama di antaranya, penelitian Ratna Ayu Yistiana pada tahun 2014 dari Universitas Pendidikan Ganesha dengan judul "Penggunaan Prinsip Kerja Sama dalam Kegiatan Berbicara Siswa Kelas VIII di MTs. Al-Khairiyah Tegallinggah Kecamatan Sukasada" dan penelitian oleh Agus Hermawan pada tahun 2015 dari Universitas Islam Malang dengan judul "Penerapan Prinsip Kerja Sama dalam Dialog ILC (Indonesia Lawyers Club), 
Tinjauan Pragmatik". Sementara itu, penelitian tentang interaksi di pasar juga sudah dilakukan, meliputi penelitian Ariesty Fujiastuti pada tahun 2014 dari Universitas Ahmad Dahlan dengan judul "Ragam Bahasa Transaksi Jual Beli di Pasar Niten Bantul" dan penelitian Try Hariadi pada tahun 2014 dari IKIP-PGRI dengan judul "Penggunaan Bahasa dalam Transaksi Jual Beli di Warung 'Bu De Sarmi' Jalan Surya Utama Jebres Surakarta (Sebuah Kajian Sosiolinguistik Lisan di Luar Kelas". Dilihat dari beberapa penelitian tersebut, belum ada penelitian yang mengkaji prinsip kerja sama pada interaksi di pasar. Oleh karena itu, penelitian ini menarik dilakukan untuk melengkapi rantai ilmu pengetahuan, khususnya pada kajian pragmatik terutama prinsip kerja sama.

Berdasarkan hal tersebut, penelitian ini bertujuan untuk mendeskripsikan (1) pematuhan prinsip kerja sama dalam interaksi jual beli di Pasar Tradisional Banyuasri, (2) pelanggaran prinsip kerja sama dalam interaksi jual beli di Pasar Tradisional Banyuasri, dan (3) implikasi prinsip kerja sama dalam interaksi jual beli terhadap pembelajaran Teks Negosiasi di kelas $\mathrm{X}$.

\section{METODE PENELITIAN}

Penelitian ini pendekatan kualitatif dengan jenis penelitian deskriptif kualitatif. Pendekatan deskriptif kualitatif digunakan untuk menganalisis dan mendeskripsikan prinsip kerja sama pada interaksi jual beli di Pasar Tradisional Banyuasri serta menjelaskan implikasinya terhadap pembelajaran Teks Negosiasi di kelas $X$.

Lokasi penelitian yang dipilih dalam penelitian ini adalah Pasar Tradisional Banyuasri. Pasar Tradisional Banyuasri berlokasi di Jalan Jenderal Ahmad Yani No. 174, Banyuasri, Kecamatan Buleleng, Kabupaten Buleleng, Provinsi Bali. Pasar ini beroperasi pada pagi dini hari sampai sekitar pukul 10.00 di los-los pasar, sedangkan pada sore hari pukul 16.00 sampai pukul 23.00 pasar ini buka di areal terminal Banyuasri. Pasar ini dipilih sebagai lokasi penelitian karena lokasinya yang cukup strategis dan menjadi tujuan berbelanja sebagian besar masyarakat di lingkungan sekitar sehingga peluang interaksi jual beli sangat besar.

Jenis data yang digunakan dalam penelitian ini adalah data kualitatif. Data kualitatif dalam penelitian ini adalah interaksi jual beli antara penjual dan pembeli. Data yang diperoleh nantinya berwujud tuturan-tuturan yang mengandung pematuhan atau pelanggaran prinsip kerja sama sehingga disajikan dalam bentuk verbal. Sementara itu, sumber data yang digunakan dalam penelitian ini adalah sumber data primer. Adapun sumber data primer dalam penelitian ini, yaitu penjual dan pembeli di Pasar Tradisional Banyuasri. Data ini bersumber dari hasil pengamatan langsung (observasi) interaksi antara penjual dan pembeli.

Dalam proses pengumpulan data, penelitian ini menggunakan metode observasi tanpa partisipasi yang didukung dengan teknik catat. Metode ini digunakan untuk memperoleh data berupa tuturan antara penjual dan pembeli sehingga dapat menjawab permasalahan pertama dan kedua, yaitu bentuk pematuhan dan pelanggaran dalam interaksi jual beli di Pasar Tradisional Banyuasri. Sementara itu, untuk menjawab permasalah ketiga digunakan metode dokumentasi berupa silabus. Metode dokumentasi digunakan untuk memperoleh implikasi penerapan prinsip kerja sama dalam interaksi jual beli terhadap pembelajaran Teks Negosiasi dengan mengaitkan pada kompetensi dasar dalam silabus.

Metode dalam pengumpulan data didukung dengan instrumen penelitian. Instrumen yang digunakan berupa catatan lapangan dan kartu data. Catatan lapangan digunakan untuk mencatat tuturan penjual dan pembeli saat melakukan observasi, sedangkan kartu data digunakan untuk menganalisis tuturan yang diperoleh saat observasi.

Setelah pengumpulan data, langkah selanjutnya adalah analisis data. Analisis data yang digunakan dalam penelitian ini 
adalah analisis deskriptif kualitatif. Adapun langkah-langkah yang dilakukan dalam analisis data, yaitu (1) reduksi data, (2) teknik analisis data tuturan dalam interaksi jual beli, (3) penyajian data, dan (4) penarikan simpulan.

\section{HASIL DAN PEMBAHASAN}

Hasil penelitian ini mencakup tiga hal, yaitu (1) pematuhan prinsip kerja sama dalam interaksi jual beli di Pasar Tradisional Banyuasri, (2) pelanggaran prinsip kerja sama dalam interaksi jual beli di Pasar Tradisional Banyuasri, dan (3) implikasi penerapan prinsip kerja sama dalam interaksi jual terhadap pembelajaran teks negosiasi di kelas $X$.

Berdasarkan pengumpulan data yang dilakukan di Pasar Tradisional Banyuasri, diperoleh 1.734 tuturan. Sebelum data-data tersebut disajikan, tahap pertama yang dilakukan adalah reduksi data. Hasil reduksi data menunjukkan ada 480 tuturan yang mematuhi prinsip kerja sama pada tuturan penjual dan 472 pematuhan pada tuturan pembeli.

\section{Pematuhan Prinsip Kerja Sama dalam Interaksi Jual Beli}

Pematuhan prinsip kerja sama pada tuturan penjual, meliputi maksim kuantitas $124(25,83 \%)$ tuturan, maksim kualitas 63 $(13,12 \%)$ tuturan, maksim relevansi 290 $(60,42 \%)$ tuturan, dan maksim pelaksanaan $3(0,63 \%)$ tuturan. Sementara itu, pematuhan prinsip kerja sama pada tuturan pembeli, meliputi maksim kuantitas 9 $(1,91 \%)$ tuturan, maksim kualitas 326 $(69,07 \%)$ tuturan, maksim relevansi 56 $(11,86 \%)$ tuturan, dan maksim pelaksanaan $81(17,16 \%)$ tuturan.

Hasil tersebut menunjukkan bahwa maksim relevansi merupakan maksim yang paling banyak dipatuhi oleh penjual, sedangkan pembeli lebih banyak mematuhi maksim kualitas. Hal ini sesuai dengan hasil penelitian yang dilakukan oleh Ratna Ayu Yistiana (2014) yang berjudul "Penggunaan Prinsip Kerja Sama dalam Kegiatan Berbicara Siswa Kelas VIII di MTs. Al-Khairiyah Tegallinggah Kecamatan Sukasada". Penelitian ini dan penelitian
Ratna Ayu Yistiana sama-sama menemukan bahwa maksim relevansi paling banyak dipatuhi oleh subjek penelitian, dalam penelitian ini subjek yang dimaksud hanya penjual. Berikut penjelasan masing-masing maksim.

\section{a) Maksim Kuantitas}

Pematuhan maksim ini dilakukan pada saat memberikan informasi mengenai harga barang maupun pada saat menolak penawaran pembeli. Berikut contoh tuturan penjual yang mematuhi maksim kuantitas.
Situasi tuturan : Seorang pembeli menanyakan harga ikan tongkol.

Tuturan pembeli : "Atenga kuda?" (Setengah berapa?)

Tuturan penjual : "Atenga lima belas. Tiga ekor menek Pak, lebih satu ons. Amun dua kuang, telu lebih" (Setengah lima belas. Tiga ekor naik Pak, lebih satu ons. Kalau dua kurang, tiga lebih)

(17 Januari 2018)

Tuturan di atas sudah sesuai dengan kaidah maksim kuantitas, "berilah sumbangan yang seinformatif-informatifnya sebagaimana yang diminta" (Sumarsono, 2010:134). Tuturan penjual memberikan pemahaman yang utuh kepada pembeli karena sudah memperoleh informasi yang jelas sehingga pembeli tidak perlu bertanya kembali tentang jumlah yang akan diperoleh.

Kemudian, pematuhan maksim kuantitas pada pembeli terjadi saat pembeli memberikan umpan balik/menjawab pertanyaan penjual dengan sangat informatif. Berikut contoh tuturan pembeli yang mematuhi maksim kuantitas.

$\begin{aligned} \text { Situasi tuturan } & \begin{array}{l}\text { Seorang } \\ \text { menanyakan pembeli }\end{array} \\ & \text { rambutan, tetapi tidak } \\ & \text { jelas rambutan mana } \\ & \text { yang dimaksud. Penjual } \\ & \text { lalu bertanya kepada } \\ & \text { pembeli. }\end{aligned}$


Tuturan pembeli : "Berapa rambutannya?" Tuturan penjual : "Yang mana?"

Tuturan pembeli : "Yang lepas-lepas ini." rambutan)

(7 Januari 2018)

Tuturan pembeli pada percakapan di atas memberikan kejelasan informasi dari segi isi tuturan dan disertai dengan gerak tangan. Pematuhan maksim ini menyebabkan penjual dapat memahami maksud pembeli dengan mudah.

\section{b) Maksim Kualitas}

Pematuhan maksim kualitas yang dilakukan oleh penjual terlihat pada saat penjual memberikan informasi tentang kualitas barang yang dijual. Selain itu, pematuhan maksim kualitas juga terjadi saat penjual memberikan informasi jumlah barang sesuai dengan hasil timbangan sehingga tuturan tersebut mengandung bukti yang memadai. Berikut salah satu contoh tuturan penjual yang mematuhi maksim kualitas.

$\begin{array}{rlr}\text { Situasi tuturan } & \begin{array}{l}\text { Seorang pembeli } \\ \text { menanyakan rasa }\end{array} \\ & \begin{array}{r}\text { rambutan yang ingin } \\ \text { dibeli setelah penjual } \\ \text { memberikan penurunan }\end{array} \\ & \text { harga. } \\ \text { Tuturan pembeli : "Manis niki?" } & \text { (Manis ini?) } \\ \text { Tuturan penjual : "Manis Pak, dados balin } & \\ & \frac{\text { siki." }}{\text { (Manis Pak, boleh }} \\ \text { dicoba satu) }\end{array}$

(7 Januari 2018)

Tuturan penjual di atas sesuai dengan kaidah maksim kualitas yang berbunyi, "jangan mengatakan sesuatu yang anda yakini bahwa itu tidak benar" (Leech, 1993:11). Pematuhan maksim kualitas pada tuturan penjual sangat membantu untuk memengaruhi sekaligus meyakinkan pembeli sehingga peluang untuk menjual barang menjadi lebih besar.

Pematuhan maksim kualitas juga terdapat pada tuturan pembeli. Berikut contoh tuturan pembeli yang mengandung pematuhan maksim kualitas.
Situasi tuturan : Setelah pembeli mengetahui harga sayap ayam, pembeli kemudian melakukan tawar- menawar.

Tuturan pembeli : "Sayap seperempat berapa?"

Tuturan penjual : "Sembilan ribu"

Tuturan pembeli : "Gak dapet delapan ribu?"

(18 Januari 2018)

Maksim kualitas merupakan maksim yang paling banyak dipatuhi oleh pembeli. Hal ini sesuai dengan posisi pembeli sebagai orang yang memerlukan informasi. Tuturannya sebagian besar berupa pertanyaan kepada penjual. Dalam konteks ini, pembeli secara tulus mengharapkan informasi dari penjual. Sesuai dengan pendapat Sumarsono (2010:133-134) mengenai maksim kualitas, yaitu "jika seseorang mengajukan pertanyaan dia mengimplikasikan bahwa dia secara tulus menginginkan jawaban". Selain pada saat menanyakan harga, pematuhan maksim kualitas juga terjadi saat tawar-menawar. Pematuhan maksim ini membantu pembeli untuk tidak melakukan pemaksaan saat menawar dengan cara menanyakan terlebih dahulu.

\section{c) Maksim Relevansi}

Pematuhan maksim relevansi pada tuturan penjual terjadi pada saat penjual memberikan informasi harga kepada pembeli. Berikut contoh tuturan penjual yang mematuhi maksim relevansi.
Situasi tuturan : Seorang pembeli menawar jaja uli (kue ketan) agar diberikan jumlah yang lebih banyak.

Tuturan pembeli : "Aji kuda jaja ne?" (Berapa harga kue ini?)

Tuturan penjual : "Delapan biji lima ribu."

Tuturan pembeli : "Sing maan sepuluh?"

(Gak dapat sepuluh?) 
Tuturan penjual : "Suba uli mekelo pitu, kutus keto gen. Ketan mael."

(Udah lama tujuh, delapan gitu aja. Ketan mahal)

(4 Januari 2018)

Tuturan penjual ketika merespon tuturan pembeli cenderung singkat, bahkan terlihat kurang sesuai dengan pertanyaan pembeli. Cara ini dilakukan agar penjual tidak terlihat menolak penawaran pembeli dan berusaha menarik perhatian pembeli dengan menawarkan barang lain yang dimiliki.

Pematuhan maksim relevansi pada tuturan pembeli terjadi pada saat memesan barang dan menyetujui harga yang ditawarkan penjual dengan cara langsung menyampaikan pesanan. Tuturan yang disampaikan sangat singkat tetapi memberikan kontribusi yang relevan terhadap tuturan penjual. Berikut contoh tuturan pembeli yang mematuhi maksim relevansi.

Situasi tuturan : Pembeli dan penjual melakukan tawarmenawar tomat yang harganya sepuluh ribu perkilo.

Tuturan pembeli : "Sing maan delapan ribu?"

(Gak dapat delapan ribu?)

Tuturan penjual : "Delapan ribu modal'e." (Delapan ribu modalnya)

Tuturan pembeli : "Akilo gen Bu." (Sekilo aja $\mathrm{Bu}$ )

(20 Januari 2018)

Pada tuturan pembeli di atas, tidak terlihat tuturan yang menunjukkan pembeli menyatakan dirinya menyepakati harga tomat. Namun, tuturan tersebut secara tidak langsung menunjukkan bahwa pembeli menyetujui harga yang disampaikan oleh penjual dengan cara langsung menyampaikan pesanan. Fenomena pada tuturan penjual dan pembeli ini menunjukkan bahwa relevansi sebuah tuturan tidak selalu terletak pada makna ujaran, tetapi juga pada sesuatu yang diimplikasikan tuturan tersebut.

\section{d) Maksim Pelaksanaan}

Pematuhan maksim pelaksanaan dalam interaksi jual beli sangat membantu mengefisienkan interaksi, khususnya saat proses tawar-menawar. Berikut contoh tuturan tersebut.

$\begin{array}{rlr}\text { Situasi tuturan } & \begin{array}{l}\text { Seorang } \\ \text { melakukan }\end{array} & \begin{array}{r}\text { pembeli } \\ \text { tawar- }\end{array} \\ & \text { menawar apel Manalagi. }\end{array}$

Tuturan pembeli : "Manalagi ne baang delapan belas nah."

(Manalagi yang ini kasi delapan belas ya)

Tuturan penjual : "Nah pilihin suba." (Ya pilih dah)

(19 Januari 2018)

Tuturan penjual pada percakapan di atas sesuai dengan kaidah maksim pelaksanaan yang disampaikan oleh Yule (2006:64), yaitu "buatlah singkat (hindarkan panjang-lebar yang tidak perlu)". Pematuhan maksim pelaksanaan menyebabkan interaksi menjadi lebih efektif dan efisien. Pembeli yang mendengarkan tuturan tersebut tidak lagi menerka-nerka maksud tuturan penjual.

Selain tuturan penjual, pematuhan maksim pelaksanaan juga dilakukan oleh pembeli. Berikut contoh tuturan pembeli yang runtut.

Situasi tuturan : Seorang pembeli menanyakan harga paha ayam. Setelah penjual menyampaikan harganya, pembeli kemudian melakukan tawar-menawar.

Tuturan pembeli : "Gak boleh ditawar?"

Tuturan penjual : "Tiga empat aja."

Tuturan pembeli : "Tiga tiga ya."

Tuturan penjual : "Gak dapat."

Tuturan pembeli : "Nyari setengah kilo, dipotong kayak lalapan."

(18 Januari 2018)

Tuturan tersebut sudah mencerminkan penyampaian yang runtut sehingga penjual dapat menentukan langkah yang harus dilakukan selanjutnya 
dengan jelas. Hal ini membuat negosiasi dapat berjalan lebih efisien karena penjual dapat dengan segera memenuhi pesanan pembeli.

\section{Pelanggaran Prinsip Kerja Sama dalam Interaksi Jual Beli}

Selain pematuhan prinsip kerja sama, pada tuturan penjual dan pembeli juga ditemukan adanya pelanggaran. Data menunjukkan terdapat 34 tuturan yang mengandung pelanggaran prinsip kerja sama yang terdapat pada tuturan penjual dan 106 tuturan yang mengandung pelanggaran prinsip kerja sama yang terdapat pada tuturan pembeli. Jika dibandingkan dengan pematuhan prinsip kerja sama, pelanggaran yang terdapat pada tuturan penjual dan pembeli menunjukkan hasil yang lebih sedikit. Hal ini menandakan bahwa penutur di pasar tradisional selalu berusaha menciptakan komunikasi yang kooperatif dalam interaksi jual beli.

Pelanggaran prinsip kerja sama pada tuturan penjual, meliputi maksim kuantitas 5 $(14,71 \%)$ tuturan, maksim kualitas 18 $(52,94 \%)$ tuturan, maksim relevansi 6 $(17,65 \%)$ tuturan, dan maksim pelaksanaan $5 \quad(14,71 \%) \quad$ tuturan. Sementara pelanggaran pada tuturan pembeli hanya ditemukan pada tiga maksim, meliputi maksim kualitas 83 (78,30\%), maksim relevansi 2 (1,89\%), dan maksim pelaksanaan $21(19,81 \%)$ tuturan. Hasil tersebut menunjukkan bahwa maksim kualitas lebih dominan dilanggar, baik itu oleh penjual maupun pembeli.

\section{a) Maksim Kuantitas}

Pelanggaran maksim kuantitas hanya terdapat pada tuturan penjual. Pelanggaran maksim kuantitas berarti melanggar kaidah yang mengharuskan penutur memberikan informasi seinformatif-informatifnya dan tidak memberikan informasi berlebihan. Berikut contoh tuturan tersebut.

Situasi tuturan : $\begin{gathered}\text { Seorang pembeli } \\ \text { menanyakan harga apel. }\end{gathered}$
Tuturan pembeli : "Kuda apel to Bu?"

Tuturan pembeli : "Kuda apel to Bu?"
(Berapa apel yang itu Bu?)

Tuturan penjual : "Apel Manalagi? Dua puluh akilo."

(Apel Manalagi? Dua puluh sekilo)

$\begin{aligned} & \text { Tuturan pembeli : "Amun ane to?" } \\ & \text { (menunjuk apel Fuji) } \\ & \text { (Kalau yang itu?) }\end{aligned}$

Tuturan penjual : "Nika pat puluh, amun ane bin sikan tiga puluh." (Itu empat puluh, kalau yang lagi satu tiga puluh)

(19 Januari 2018)

Pelanggaran maksim ini dilakukan oleh penjual dengan tujuan tertentu. Melalui pelanggaran ini, penjual berusaha meminimalkan pembatalan pembeli untuk berbelanja dengan cara langsung memberikan alternatif lain. Hal ini juga digunakan untuk mencegah penawaran yang terlalu rendah.

\section{b) Maksim Kualitas}

Pelanggaran maksim kualitas pada tuturan penjual terjadi pada saat tawarmenawar. Ketika pembeli sudah mengajukan penawaran, biasanya penjual mengatakan bahwa harga yang diberikan sudah murah. Selain itu, penjual juga kerap mengatakan bahwa harga barang sudah naik tanpa disertai bukti yang memadai. Hal ini tidak sesuai dengan pendapat Leech (1993:11) tentang maksim kualitas, yaitu "penutur jangan mengatakan sesuatu yang bukti kebenarannya kurang meyakinkan". Berikut contoh tuturan penjual yang mengandung pelanggaran maksim kualitas.

Situasi tuturan : Seorang pembeli menanyakan harga buncis dan melakukan tawar-menawar.

Tuturan pembeli : "Meli buncis Pak. Aji kuda akilo?"

(Beli buncis Pak. Berapa sekilo?)

Tuturan penjual : "Dua belas."

Tuturan pembeli : "Sepuluh nah. Kan saisai melanja dini." 
(Sepuluh ya. Kan seringsering belanja di sini)

Tuturan penjual : "Sing maan ji monto. Suba mudah gati." (Gak dapat segitu. Udah murah sekali)

(3 Januari 2018)

Kemudian, pelanggaran maksim kualitas pada tuturan pembeli terjadi pada saat pembeli melakukan penawaran. Berikut contoh tuturan pembeli yang mengandung pelanggaran maksim kualitas.

Situasi tuturan : Seorang pembeli menanyakan harga setengah kilo sayur kubis/kol. Setelah itu, terjadilah tawarmenawar.

Tuturan pembeli : "Nyari satu setengah, berapa?"

Tuturan penjual : "Delapan ribu"

Tuturan pembeli : "Tujuh ribu kasi ya."

Tuturan penjual : "Delapan ribu pasnya."

Tuturan pembeli : "Tujuh ribu dah ya."

Penjual : (menaruh kol pada timbangan)

(20 Januari 2018)

Tuturan di atas melanggar kaidah maksim kualitas, yaitu "jangan mengatakan sesuatu yang diyakini salah" (Yule, 2006:64). Pelanggaran ini dilakukan bertujuan untuk memperoleh harga yang lebih murah sehingga meskipun pembeli sudah menyadari bahwa yang disampaikan salah, pelanggaran ini tetap dilakukan.

\section{c) Maksim Relevansi}

Penutur dikatakan melanggar maksim relevansi apabila tidak mampu memberikan kontribusi yang relevan tentang sesuatu yang sedang dibicarakan. Pelanggaran maksim relevansi dilakukan oleh penjual untuk mempersingkat interaksi, khususnya saat tawar-menawar. Berikut contoh tuturan penjual yang melanggar maksim relevansi.

Situasi tuturan : Seorang pembeli menawar jagung yang harganya sembilan ribu perbungkus.

Tuturan pembeli : "Sing dadi tawah?" (Gak boleh ditawar?)

\author{
Tuturan penjual : "Pat isine, gede-gede \\ gati bin." \\ (Empat isinya, besar- \\ besar sekali lagi)
}

(9 Januari 2018)

Tuturan tersebut tidak menunjukkan adanya relevansi dengan pertanyaan pembeli. Meskipun demikian, nampaknya sebagian pembeli dapat memahami maksud penjual sehingga tidak terlalu mengganggu interaksi. Tuturan dengan mengalihkan pembicaraan sering dilakukan penjual untuk menolak penawaran pembeli.

Pelanggaran maksim relevansi juga terdapat pada tuturan pembeli. Berikut tuturan pembeli yang melanggar maksim relevansi.

Situasi tuturan : Seorang pembeli

melakukan tawar-

menawar mangga wani.

Setelah memperoleh

kesepakatan, penjual

lalu menawarkan pembeli buah jeruk.

Tuturan pembeli : "Wayah niki?" (Matang ini?)

Tuturan penjual : "Mani tasak ampun Bu. Semaga ten ngalih?"

(Besok matang dah Bu. Jeruk gak nyari?)

Tuturan pembeli : "Salak dua kilo Bu. Ane becik-becik baang." (Salak dua kilo Bu. Yang bagus-bagus kasi)

(7 Januari 2018)

Pelanggaran pada tuturan pembeli umumnya jarang terjadi. Kalaupun terjadi pelanggaran, maka ada dorongandorongan lain yang memengaruhi, seperti kurangnya minat terhadap barang yang ditawarkan. Hal ini sesuai dengan pendapat Wijana yang telah dijelaskan sebelumnya.

\section{d) Maksim Pelaksanaan}

Ketika berinteraksi, penjual sering berbicara tidak jelas atau kurang lengkap. Hal tersebut berdampak terhadap proses tawar-menawar yang menjadi kurang komunikatif karena tidak semua pembeli 
dapat memahami jawaban singkat dari penjual. Berikut tuturan penjual yang melanggar maksim pelaksanaan.

$\begin{array}{rlr}\text { Situasi tuturan } & \begin{array}{l}\text { Seorang } \\ \text { menanyakan } \\ \text { rambutan. }\end{array} & \begin{array}{r}\text { pembeli } \\ \text { harga }\end{array} \\ & \end{array}$

Tuturan pembeli : "Kuda buluan ne Bu?"
(Berapa rambutannya $\mathrm{Bu}$ ?)

Tuturan penjual : "Dua belas Pak."

Tuturan pembeli : "Dua belas agencet?"

(Dua belas seikat?)

Tuturan penjual : "Ten, akilo Pak. Nah sepuluh ampun ambil."

(Nggak, sekilo Pak. Ya sepuluh aja ambil)

(7 Januari 2018)

Sementara itu, pelanggaran maksim pelaksanaan yang terdapat pada tuturan pembeli sering terjadi saat pembeli menanyakan barang maupun menyampaikan jumlah pesanan. Tuturan yang disampaikan oleh pembeli sering tidak jelas sehingga penjual harus menanyakan kembali untuk memperoleh informasi yang utuh. Berikut contoh tuturan tersebut.

$\begin{array}{rlr}\text { Situasi tuturan } & \begin{array}{l}\text { Seorang } \\ \text { menanyakan } \\ \text { jeruk. }\end{array} & \begin{array}{r}\text { pembeli } \\ \text { harga }\end{array} \\ & \end{array}$

Tuturan pembeli : "To kuda Bu?"

Tuturan penjual : "Ane cen?"

(Yang mana?)

Tuturan pembeli : "Semaga ne."

(Jeruknya)

(7 Januari 2018)

Pelanggaran maksim pelaksanaan yang terjadi pada tuturan penjual dan pembeli paling banyak melanggar kaidah yang berbunyi, "hindarilah pernyataanpernyataan yang samar" (Leech, 1993:11). Pelanggaran maksim ini menyebabkan negosiasi menjadi kurang efektif karena peserta tutur harus menanyakan kembali untuk memperoleh kejelasan.

\section{Implikasi Prinsip Kerja Sama dalam Interaksi Jual Beli terhadap Pembelajaran Teks Negosiasi}

Sesuai dengan Kurikulum 2013, pembelajaran Bahasa Indonesia saat ini adalah berbasis teks. Sebagian besar guruguru Bahasa Indonesia menggunakan teks yang ada pada buku ajar sebagai bahan pembelajaran. Sangat jarang guru memberikan teks di luar buku ajar. Padahal sangat banyak sumber-sumber yang bisa digunakan agar siswa memperoleh teks yang beragam, salah satunya memanfaatkan lingkungan sekitar seperti pada penelitian ini.

Pembelajaran Teks Negosiasi di SMA dilaksanakan berdasarkan silabus. Guruguru Bahasa Indonesia mengajarkan konsep-konsep teks negosiasi sesuai dengan KD yang dimuat dalam silabus. Bahan ajar yang baik adalah bahan ajar yang mampu mewadahi kompetensi dasar pada setiap materi. Untuk melihat implikasi sekaligus relevan tidaknya hasil penelitian ini terhadap pembelajaran Teks Negosiasi, maka akan dikaitkan dengan KD yang terdapat pada materi teks negosiasi. Adapun KD yang terdapat pada materi Teks Negosiasi meliputi KD:
3.10 Mengevaluasi
pengajuan, penawaran, dan persetujuan dalam teks negosiasi lisan maupun tertulis.
4.10 Menyampaikan
pengajuan, penawaran, persetujuan, dan penutup dalam teks negosiasi secara lisan atau tulis.

3.11 Menganalisis isi, struktur (orientasi, pengajuan, penawaran, persetujuan, penutup), dan kebahasaan teks negosiasi.

4.11 Mengkonstruksikan teks negosiasi dengan memperhatikan isi, struktur (orientasi, pengajuan, penawaran, persetujuan, penutup), dan kebahasaan.

Tuturan negosiasi yang diperoleh dalam penelitian ini dapat dijadikan contoh teks saat pembelajaran pada masingmasing KD. Salah satu contoh tuturan dalam penelitian ini sebagai berikut.

Pembeli : "Manis niki buluan ne Bu?"

(Manis ini rambutannya Bu?) 
Penjual : "Manis Pak, tolih je seger barakne."

(Manis Pak, lihat aja segar merahnya)

Pembeli : "Aji kuda?"

(Berapa?)

Penjual : "Tiga belas akilo."

(Tiga belas sekilo)

Pembeli : "Ten maan sepuluh?"

(Gak dapat sepuluh?)

Penjual : "Buluan manis niki Pak."

(Rambutan manis ini Pak)

(Percakapan 31/4 Januari)

Melalui tuturan di atas, siswa dapat belajar mengevaluasi pengajuan, penawaran, dan persetujuan dalam negosiasi sesuai dengan yang tercantum pada kompetensi dasar. Dalam penerapan prinsip kerja sama siswa belajar bahwa (1) sesuai maksim kuantitas, penjual harus memberikan informasi yang informatif kepada pembeli agar pengajuan dapat dipahami dan diterima oleh pembeli; (2) sesuai maksim kualitas, penjual harus menyertakan alasan saat menyampaikan pengajuan untuk meyakini pembeli, serta saat penawaran pembeli harus meminta informasi secara tulus sehingga penawaran tidak terkesan memaksa; (3) sesuai maksim relevansi, penjual dan pembeli harus memberikan kontribusi yang relevan agar negosiasi berjalan efektif; dan (4) sesuai maksim pelaksanaan, penjual dan pembeli harus berbicara langsung dan jelas agar negosiasi dapat berjalan lancar dan efisien. Hal-hal tersebut menjadi poin tambah dan sangat mendukung pemahaman siswa mengenai teks negosiasi.

Sementara itu, dalam pelanggaran prinsip kerja sama siswa dapat mencermati dampak yang ditimbulkan, seperti negosiasi berjalan kurang efektif. Siswa juga dapat mencermati penyebab terjadinya pelanggaran dan pengaruhnya terhadap kelancaran negosiasi.

\section{SIMPULAN DAN SARAN}

Berdasarkan hasil dan pembahasan, ada beberapa hal yang dapat disimpulkan dalam penelitian ini.
Pertama, pematuhan prinsip kerja sama pada tuturan penjual dan pembeli ditemukan pada keempat maksim. Tuturan penjual berjumlah 480 tuturan yang meliputi, maksim kuantitas 124 (25,83\%) tuturan, maksim kualitas $63 \quad(13,12 \%)$ tuturan, maksim relevansi 290 (60,42\%) tuturan, dan maksim pelaksanaan 3 $(0,63 \%)$ tuturan. Sementara itu, pematuhan prinsip kerja sama pada tuturan pembeli berjumlah 472 tuturan yang meliputi, maksim kuantitas $9(1,91 \%)$ tuturan, maksim kualitas $326(69,07 \%)$ tuturan, maksim relevansi $56(11,86 \%)$ tuturan, dan maksim pelaksanaan $81(17,16 \%)$ tuturan. Hasil tersebut menunjukkan bahwa, pematuhan prinsip kerja sama pada tuturan penjual lebih dominan menerapkan maksim relevansi, sedangkan pada tuturan pembeli lebih dominan menerapkan maksim kualitas.

Kedua, pelanggaran prinsip kerja sama pada tuturan penjual terdapat pada keempat maksim, sedangkan pada tuturan pembeli hanya terdapat pada tiga maksim. Tuturan penjual berjumlah 34 tuturan yang meliputi, maksim kuantitas 5 (14,71\%) tuturan, maksim kualitas 18 (52,94\%) tuturan, maksim relevansi $6 \quad(17,65 \%)$ tuturan, dan maksim pelaksanaan 5 $(14,71 \%)$ tuturan. Sementara pelanggaran pada tuturan pembeli berjumlah 106 tuturan yang meliputi, tidak ditemukan pelanggaran pada maksim kuantitas, maksim kualitas 83 (78,30\%), maksim relevansi $2(1,89 \%)$, dan maksim pelaksanaan $21(19,81 \%)$ tuturan. Hasil tersebut menunjukkan bahwa, maksim kualitas paling dominan dilanggar, baik oleh penjual maupun pembeli.

Ketiga, prinsip kerja sama dalam interaksi jual beli berimplikasi terhadap pembelajaran teks negosiasi kelas $X$. Pematuhan maksim kuantitas dan kualitas sangat penting diterapkan saat menyampaikan pengajuan karena informasi yang cukup dan alasan-alasan yang memadai akan membantu mitra tutur memahami pengajuan dengan baik. Pematuhan maksim kualitas saat penawaran juga penting diajarkan kepada siswa agar dalam menyampaikan 
penawaran tidak mengandung pemaksaan karena dalam maksim kualitas siswa belajar meminta informasi secara tulus. Pematuhan maksim relevansi dan pelaksanaan juga berperan penting agar siswa dapat menciptakan negosiasi yang efektif dan mencapai persetujuan. Selain itu, terkait pelanggaran yang terjadi, siswa dapat belajar bahwa pelanggaran prinsip kerja sama dapat menyebabkan negosiasi berjalan tidak efektif. Namun, ada hal-hal tertentu yang ingin dicapai, seperti untuk memberikan pilihan kepada pembeli. Halhal tersebut dapat disesuaikan dengan kompetensi dasar (KD) dalam materi teks negosiasi.

Berdasarkan hasil penelitian dan simpulan di atas, saran yang dapat disampaikan dalam penelitian ini adalah sebagai berikut.

Pertama, bagi guru diharapkan penelitian ini dapat dijadikan bahan ajar tambahan dengan menyelipkan konsep tentang membangun kerja sama dalam berkomunikasi, khususnya pada pembelajaran Teks Negosiasi. Selain itu, guru juga diharapkan dapat meningkatkan kepekaan terhadap sumber-sumber belajar yang ada di lingkungan sekitar, seperti pemanfaatan pasar tradisional sebagai sumber belajar siswa untuk mendalami pemahaman tentang negosiasi.

Kedua, bagi pembaca diharapkan agar prinsip kerja sama dapat diterapkan dalam berkomunikasi pada kehidupan sehari-hari, baik itu pada ranah formal maupun informal. Hal ini bertujuan agar terjalin komunikasi yang efektif sehingga tidak ada informasi yang berlebihan, tidak jelas, dan tidak benar yang berujung pada kesalahpahaman.

Ketiga, bagi penelitian lain diharapkan mampu mengkaji interaksi jual beli dari segi lain. peneliti lain bisa meneliti pola komunikasi dalam interaksi jual beli sehingga penelitian tentang interaksi jual beli menjadi lebih kompleks.

\section{DAFTAR PUSTAKA}

Bilas, Richard A. 1992. Teori Mikroekonomi. Jakarta: Penerbit Erlangga.
Djatmika. 2014. Pernik Kajian Wacana. Yogyakarta: Graha Ilmu.

Fuad, M., dkk. 2000. Pengantar Bisnis. Jakarta: PT Gramedia.

Fujiastuti, Ariesty. 2014. "Ragam Bahasa Transaksi Jual Beli di Pasar Niten Bantul" Jurnal Bahastra, Volume 32, Nomor 1 (15-34).

Hariadi, Try. 2014. "Penggunaan Bahasa dalam Transaksi Jual Beli di Warung 'Bude Sarmi' Jalan Surya Utama Jebres Surakarta (Sebuah Kajian Sosiolinguistik Lisan di Luar Kelas)" Jurnal Pendidikan Bahasa, Volume 3, Nomor 2 (hlm. 253-266).

Hermawan, Agus. 2015. "Penerapan Prinsip Kerja Sama dalam Dialog ILC (Indonesia Lawyers Club), Tinjauan Pragmatik" Jurnal NOSI, Volume 3, Nomor 4 (hlm. 479-487).

Putrayasa, I.B. 2014. Pragmatik. Yogyakarta: Graha IImu.

Rahardi, Kunjana. 2005. Pragmatik; Kesantunan Imperatif Bahasa Indonesia. Jakarta: Penerbit Erlangga.

Sumarsono. 2010. Pragmatik. Singaraja: Universitas Pendidikan Singaraja.

Syahroni, Ngalimun, dkk. 2013. Bahasa Indonesia di Perguruan Tinggi. Yogyakarta: Aswaja Pressindo.

Wisudariani, Rai. 2013. Bahan Ajar Pragmatik. Singaraja: Universitas Pendidikan Ganesha.

Yistiana, Ratna Ayu. 2014. Penggunaan Prinsip Kerja Sama dalam Kegiatan Berbicara Siswa Kelas VIII di MTs. AlKhairiyah Tegallinggah Kecamatan Sukasada. Skripsi (tidak diterbitkan). Jurusan Pendidikan Bahasa dan Sastra Indonesia, Universitas Pendidikan Ganesha.

Yule, George. 2006. Pragmatik. Terjemahan Indah Fajar Wahyuni. Pragmatics. 1993. Yogyakarta: Pustaka Pelajar. 